Pain and Palliative Care Unit, Instituto Nacional de Cancerología. Bogotá, Colombia.

Correspondence: Unidad de Dolory Cuidados Paliativos, Instituto Nacional de Cancerología, ESE. Calle 1\# 9-85. Bogotá, Colombia.

E-mail:quintero0423@gmail.com

\section{What do we know about this} problem?

- Neuropathic pain in cancer patients is a highly prevalent symptom probably resulting from the direct damage inflicted by the neoplasm or from secondary damage derived from the cancer treatment, as is the case with this particular patient, who developed pain following the femoral nerve injury during cancer surgery.

- The evidence of neuropathic pain management through spinal cord stimulation, specifically in cancer patients, is based on small trials and case reports.

What new contributions does this study make?

- Evidence supporting the use of medullary neurostimulation for neuropathic pain management in cancer patients.

- Discussion and brief literature review about neuropathic pain, epidemiological data, risk factors, medullary neurostimulation and its indications in patients with chronic cancer pain, in particular neuropathic pain.

How to cite this article

Quintero-Carreño V, Molina BM, Rodríguez-Martínez $\mathrm{CH}$. Spinal cord stimulation in the management of neuropathic pain in cancer patients: case report. Colombian Journal of Anesthesiology. 2021;49:e934.

\section{Abstract}

\section{Introduction}

Neuropathic pain is present in up to $40 \%$ of all cancer patients. A considerable number of patients fail to achieve enough pain relief with conventional treatment, which is why therapeutic alternatives such as spinal cord stimulation should be considered.

\section{Case description and results}

This is the case of a female patient with chronic neuropathic pain secondary to a partial femoral nerve injury sustained during resection and lymph node dissection surgery with curative intent for a large stage II cell squamous cell carcinoma $\mathrm{T} 2 \mathrm{NoMo}$, localized in the right popliteal fossa. The patient presented with difficult to manage chronic neuropathic pain, despite receiving multiple oral analgesics and nerve blocks. $A$ medullary neurostimulator was implanted that relieved the patient's pain intensity in up to $80 \%$, in addition to improved function and quality of life.

\section{Conclusions}

Spinal cord stimulation is considered an effective neuromodulatory intervention which has shown satisfactory results in the treatment of various types of refractory chronic pain in cancer patients, including neuropathic pain.

Key words

Neuropathic pain; spinal cord stimulation; cancer; chronic pain; case report.

\section{Resumen}

Introducción

El dolor neuropático está presente hasta en el $40 \%$ de los pacientes con cáncer. Un número considerable de pacientes no logran un alivio suficiente del dolor con el tratamiento convencional, por lo cual deben considerarse alternativas terapéuticas como la estimulación de la médula espinal.

\section{Descripción del caso y resultados}

Caso de una paciente con dolor neuropático crónico secundario a lesión parcial de nervio femoral durante cirugía de resección y vaciamiento ganglionar con objetivos curativos de carcinoma escamocelular de célula grande T2NoMo estadio II, localizado en la fosa poplítea derecha, quien cursó con dolor neuropático crónico de difícil manejo a pesar de recibir múltiples analgésicos orales y bloqueos nerviosos. Se implantó un neuroestimulador medular con lo cual se logró un alivio hasta del $80 \%$ en intensidad de dolor de la paciente, además de una mejoría de su funcionalidad y calidad de vida.

\section{Conclusiones}

La estimulación de la médula espinal se considera una intervención neuromoduladora eficaz, que ha demostrado resultados satisfactorios para tratar diversas formas de dolor crónico refractario en los pacientes con cáncer, incluido el dolor neuropático.

\section{Palabras clave}

Dolor neuropático; estimulación de la médula espinal; cáncer; dolor crónico; reporte de caso. 


\section{INTRODUCTION}

Pain in cancer patients is a highly prevalent symptom; it is estimated that between 65 $\%$ to $85 \%$ of cancer patients experience pain at some point over the course of their disease. Of these, $20 \%$ corresponds to neuropathic pain and up to $40 \%$ is mixed pain (neuropathic and nociceptive). $(1,2)$ Neuropathic is defined as "pain caused by a lesion or disease affecting the somatosensory system " $\underline{(2,3)}$ and it may lead both to loss of function and increased sensitivity, and to spontaneous pain. $(3,4)$

In cancer patients, the source of neuropathic pain may be the direct nervous system injury from the primary tumor or metastasis, or it may be secondary to the cancer therapy (surgery, chemotherapy or radiotherapy). (5) Neuropathic pain has been associated with poor outcomes, increased requirements for analgesics, worse physical, cognitive and social performance, as compared to patients who are free from nociceptive pain. $(6,7)$ Approximately $10 \%$ to $15 \%$ of the patients with cancer-related pain fail to relief the pain with opioids alone, or in combination with adjuvant analgesics. (8) Spinal cord stimulation (SCS) has been suggested as an effective technique within the therapeutic armamentarium for the management of different cancer-related types of pain. $\underline{(8,9)}$

\section{CASE REPORT}

This is a 60-year old woman who works as a peddler, with a history of large cell squamous cell carcinoma T2NoMo stage II, localized in the right popliteal fossa. The patient underwent lymph node emptying with curative intent in July 2006. She sustained a partial femoral nerve lesion in the groin, confirmed by electrodiagnostic tests; later she developed localized neuropathic pain of the right anterior lower extremity, from the middle third of the thigh down to the middle third of the leg, with a pain intensity of $9 / 10$ according to the analogue numerical rating scale (NRS), which decreased to $8 / 10$ with oral analgesia and/or rest.

\section{CLINICAL FINDINGS}

The patient presented areas of allodynia and hyperalgesia in the area of the right femoral and saphenous nerves (dermatomes L2, L3, L4) (Figure 1), decreased muscle strength $3 / 5$ in the flexors of the hip and of the right knee, 4/5 in the dorsi and plantar-flexors of the right foot, and steppage gait that required cane support. The pain became difficult to manage, so different high-dose analgesia regimens were required over approximately 8 years, with various types of drugs, neuromodulators (pregabalin and gabapentin), antidepressants (amitriptyline), anticonvulsants, (oxcarbazepine), and potent opioids (methadone, oxycodone and transdermal buprenorphine), in addition to interventionist management (two translaminar epidural blocks L2-L3 and a sympathetic right L4 block), with which the patient achieved partial pain control.

\section{THERAPEUTIC INTERVENTION}

The patient experienced chronic, high intensity neuropathic pain, with poor response to the multiple pharmacological analgesia regimens and interventional management. She has limited mobility and function, with significant quality of life impact. In 2014 medullary stimulation management was considered, and following a positive test conducted in October 2017, a neurostimulator (NS) was implanted in January 2019 (Figure 2), with no immediate or post-intervention complications.

It is important to say that notwithstanding the early indication for SN management, both the test and the implant were delayed for approximately 5 years, because of numerous administrative and authorization problems with the health insurance.

\section{FOLLOW-UP AND RESULTS}

Progressive pain relief was observed following the NS implant, with a reduction in pain intensity of "up to $80 \%$ ", as reported by the patient 3 months after the procedure (NRS 2/10), which enabled her to resume her work and daily life activities. The potent opioid was switched to a milder opioid and, due to the persistent areas or allodynia, the patient continues with low dose neuromodulators.

FICURE 1. A. Surgical wound in the popliteal area of the right lower extremity. B. Areas of allodynia and hyperalgesia in territories of the femoral and saphenous nerves in the anterior aspect of the right lower extremity.
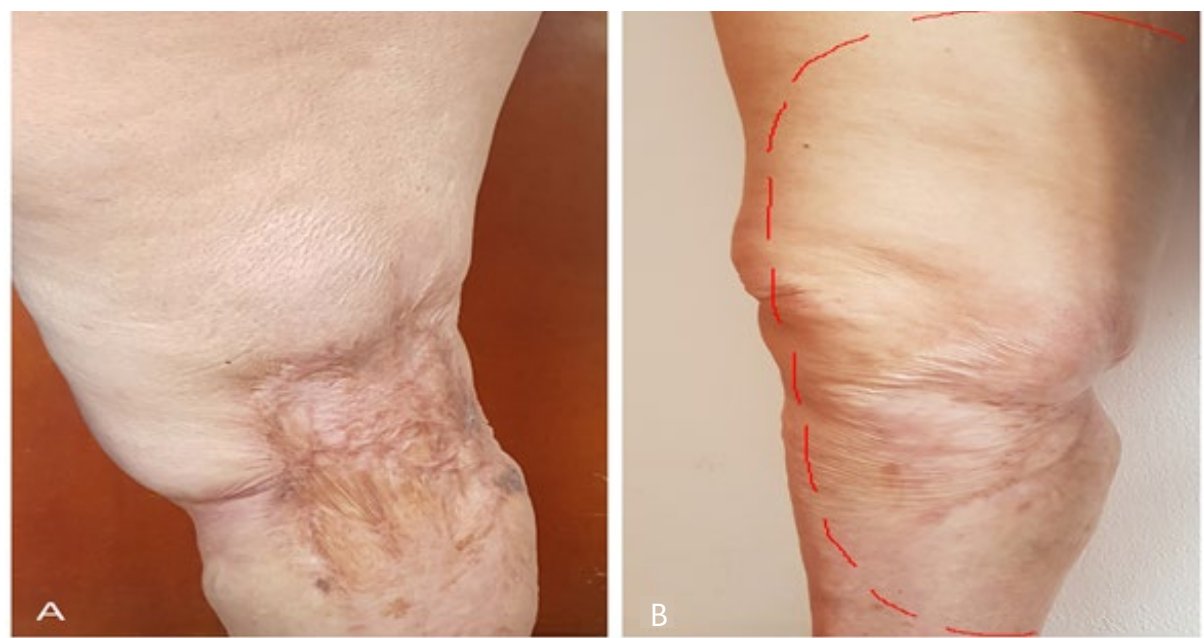

SOURCE: Authors 
FIGURE 2. Medullary neurostimulator with T12 leads.

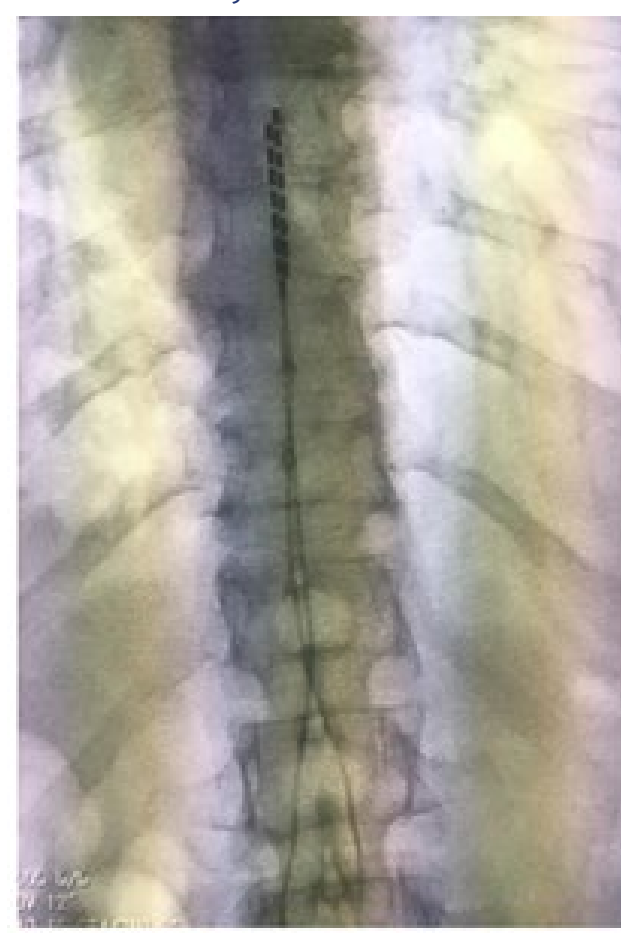

SOURCE: Authors.

\section{DISCUSSION}

Neuropathic pain is a complex process involving maladaptation mechanisms and neuroplastic changes in response to a peripheral nervous system (PNS) injury. (9) Regardlessofthecause, neuropathicpainisthe result of hyperexcitability and sensitization phenomena. (10) Hyperexcitability is secondary to the generation of spontaneous discharges and of abnormal responses to depolarizing stimuli (mechanical, thermal or chemical) that present in the injured nerve. Ectopic discharges cause changes in the PNS and in the Central Nervous System (CNS), which are referred to as central sensitization. (10). These changes explain the phenomenon of allodynia in which a harmless stimulus triggers disproportionate pain, due to a reduction of the nociceptors activation threshold. $(10,11)$

The SCS technique is a nonpharmacologic, minimally invasive approach for the management of neuropathic and nociceptive pain. (12) Its effectiveness has been proven particularly in chronic pain conditions such as the

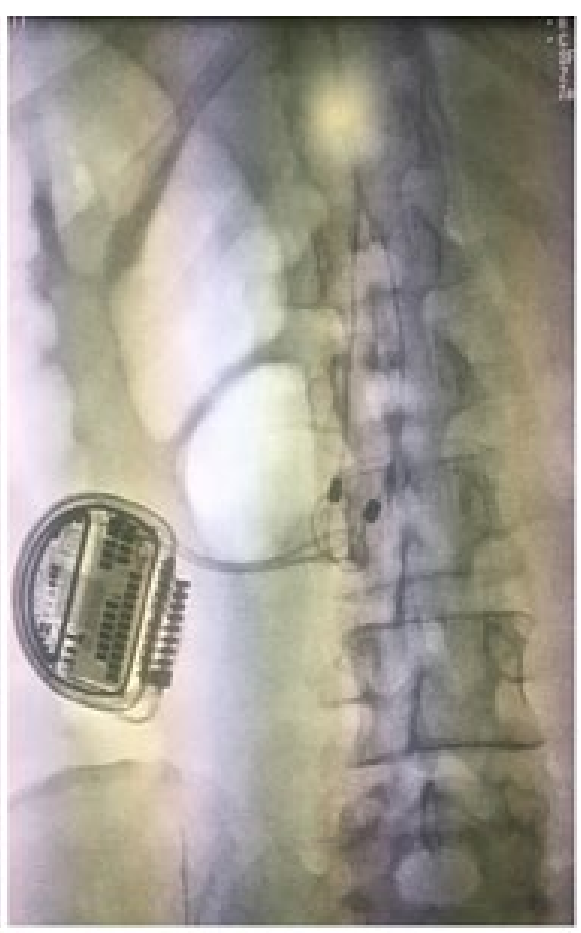

region of the $\mathrm{C}$ fibers, may cause the "gate" to close and hence block the transmission of pain impulses. $(9,18)$

Based on this theory, Shealy et al., implanted the first dorsal spine stimulator in 1967 for the treatment of pain. $(12,14)$ However, several decades of research have shown that the exact underlying mechanisms of the SCS-induced analgesia to control pain are much more complex and continue to be investigated; specifically, in neuropathic pain, but these mechanisms have not been fully explored. $(9,12,17)$

It has been shown that SCS may modulate different components of neuropathic pain, including allodynia, and it also has an anti-ischemic action which makes it effective in the management of specific pain syndromes, both ischemic and neuropathic. $\underline{(11,15)}$ The available evidence about the use of SCS for the management of neuropathic pain in cancer patients is still limited; however, the accumulated evidence from studies in animal models supports a mechanisms suggested for controlling neuropathic pain. (8) Furthermore, there are case reports that may support its use when the pain is refractory to other treatment modalities. $\underline{(16,17)}$ treatment of intractable chronic pain of various causes, including cancer-related pain. (15-17)

The SCS technique consists in the application of electricity to the dorsal columns of the spinal cord, to modulate/ manipulate the pain signals carried by the ascending tracts. $\underline{(9,12)}$ The SCS concept is based on the "theory of the pain gate" suggested by Melzack and Wall in 1965 (18), which argues the existence of a "gate" in the dorsal horn of the spinal cord (DHSC) that controls the flow of neuronal impulses from the sensory afferent neurons to the upper brain centers. $(8,9)$ The $A \beta$ fibers (responsible for transporting the nonnociceptive stimuli) and the $C$ fibers (responsible for transporting the pain stimuli) form synapsis with the projection neurons of the spinothalamic tract in the DHSC, responsible for transmitting pain. $(12,18) A \beta$ fibers stimulation in the same

\section{CONCLUSIONS}

A case of neuropathic pain secondary to cancer therapy, refractory to conventional therapies was discussed, which was successfully treated using medullary neurostimulation. This technique may be an effective therapeutic option for cancer patients with difficult to manage neuropathic pain, in whom the available therapies have been exhausted. The patient experienced improvement of her neuropathic pain, was able to reduce the use of opioid analgesics and neuromodulators, was able to resume her activities of daily living and her quality of life improved. She continues to be followed by the Pain and Palliative Care Clinic and authorized the publication of her case. 


\section{ETHICAL RESPONSIBILITIES}

\section{Protection of humans and animals}

The authors claim that no experiments in humans or animals were conducted for this research project.

\section{Confidentiality of the information}

The authors declare that no patient data are disclosed in this article.

\section{Right to privacy and informed consent}

The patient submitted her informed consent in writing, authorizing the authors to use her data, pictures, and clinical images to report her case, for academic and scientific purposes.

\section{ACKNOWLEDGEMENTS}

\section{Contributions}

VQC: planning of the study, data collection, literature search, data analysis, initial drafting of the manuscript, and final draft.

BMMA and CHRM: case identification study planning, data analysis, final drafting of the manuscript and final approval.

\section{Funding}

None declared.

\section{Conflicts of interest}

The authors have no conflicts of interest to disclose.

\section{REFERENCES}

1. Boland E, Mulvey M. Classification of neuropathic pain in cáncer patients, Review. Curr Opin Support Palliat Care. 2015;9:112-5. doi:10.1097/SPC.0000000000000136.

2. Edwards H, Mulvey M, Bennett M. Cancer-related neuropathic pain. Cancers. 2019;11(3):373. doi: $10.3390 /$ cancers 11030373

3. Jensen TS, Baron R, Haanpaa M, Kalso E, Loeser JD, Rice AS, Treede RD. A new definition of neuropathic pain. Pain. 2011;152:2204-5. doi: 10.1016/j.pain.2011.06.017

4. Pérez S, Acosta A. Consenso mexicano de manejo de dolor por cáncer. Gaceta Mexicana de Oncología. 2016;15(Supl 1):3-34.

5. Bennett MI, Rayment C, Hjermstad M, Aass N, Caraceni A, Kaasa S. Prevalence and aetiology of neuropathic pain in cancer patients: $A$ systematic review. Pain. 2012;153:359-65. doi: 10.1016/j.pain.2011.10.028

6. Rayment C, Hjermstad M], Aass N, Kaasa S, Caraceni A, Strasser F, et al. Neuropathic cancer pain: Prevalence, severity, analgesics and impact from the European Palliative Care Research Collaborative-Computerised Symptom Assessment study. Palliat Med. 2013;27:71421. doi: $10.1177 / 0269216312464408$

7. Fallon M. Neuropathic pain in cáncer. $\mathrm{Br}$ ] Anaesthesia. 2013;111(1):105-11. doi:10.1093/ bja/aet208

8. Flagg A, McGreevy K, Williams K. Spinal cord stimulation in the treatment of cancer-related pain: "Back to the Origins". Curr Pain Headache Rep. 2012;16(4):343-9. doi:10.1007/ s11916-012-0276-9
9. Eisenberg E, Burstein Y, Suzan E. Spinal cord stimulation attenuates temporal summation in patients with neuropathic pain. PAIN. 2015;156(3):381-5. doi: 10.1097/01.j.pa in.0000460342.69718.a2.

10. Zarranz J]. Dolor. En: Neurología. Sexta edición. Elsevier España, S.L.U; 2018. p. 235-48.

11.Papuć E, Rejdak K. The role of neurostimulation in the treatment of neuropathic pain. Ann Agric Environ Med. 2013;20(1):14-7.

12. Deer T, Jain S, Hunter C, Chakravarthy K. Neurostimulation for intractable chronic pain. Brain Sci. 2019;9(2):23. doi:10.3390/brainsci9020023

13. Cameron T. Safety and efficacy of spinal cord stimulation for the treatment of chronic pain: a 20-year literature review. ] Neurosurg. 2004;100:254-67. doi: 10.3171/ spi.2004.100.3.0254

14. Shealy CN, Mortimer JT, Reswick JB. Electrical inhibition of pain by stimulation of the dorsal columns: Preliminary clinical report. Anesth Analg. 1967;46:489-91.

15. Yakovlev AE, Ellias Y. Spinal cord stimulation as a treatment option for intractable neuropathic cancer pain. Clin Med Res. 2008;6(34):103-6. doi: $10.3121 / \mathrm{cmr} .2008 .813$

16. Yakovlev AE, Resch BE. Spinal cord stimulation for cancer-related low back pain. Am J Hosp Palliat Med. 2011;29(2):93-7. doi:10.1177/1049909111410414

17. Yakovlev AE, Resch BE, Karasev SA Treatment of cancer-related chest wall pain using spinal cord stimulation. Am ] Hosp Palliat Med. 2010;27(8):552-6. doi:10.1177/1049909110373240

18. Melzack R, Wall PD. Pain mechanisms: A new theory. Science. 1965;150(3699):971-8. doi:10.1126/science.150.3699.971 